\title{
Economic Evaluation of Kinnow Cultivation under Different Irrigation Systems in Rajasthan
}

\author{
N.K. Meena, Ram Singh*, S.M. Feroze, R.J. Singh and A.K. Singh \\ College of Post Graduate Studies, Central Agricultural University (Imphal), Umiam, Meghalaya, India \\ *Corresponding author: ramsingh.cau@gmail.com
}

\begin{abstract}
The present study was conducted in Sri-Ganganagar and Bikaner districts of Rajasthan. Kinnow cultivation under different irrigation system viz.; solar, diesel and electric irrigation system was found to be popular in the state. Therefore, study on economic evaluation of kinnow cultivation under different irrigation system in Rajasthan has been conducted to evaluate kinnow orchard orchards under different irrigation system. Total 240 respondents were selected for the study. Standard techniques like NPV, BC ratio, IRR, Break-Even point and Payback period were employed. The investment in kinnow orchard has been seen as profitable business. In the study area, the net present value was work out to be ₹ 842521 per ha under solar irrigation system ₹ 798964 per ha electric irrigation system and ₹ 762808 per ha under diesel irrigation system. Internal rate of return was found to be 38 per cent, 37 per cent and 35 per cent under solar irrigation, electric irrigation and diesel irrigation system. Benefit-Cost Ratio was at 2.36, 2.23 and 2.08 under solar, electric and diesel irrigation system. Break-Even point was 5.82 ton, 4.79 ton and 6 ton under solar, diesel and electric irrigation system. Payback period estimated to be 7.1 years, 7.2 years and 7.3 year under solar, electric and diesel irrigation system. Hence, the kinnow orchard with solar irrigation system has been found to be very economic feasible and it should be realized to the farming community for attraction towards use of renewable energy in fruits production in the state.
\end{abstract}

Keywords: NPV, IRR, BCR, Kinnow, solar, and Rajasthan

Horticultural sector has been played an important role in providing the livelihood security to the farmers under the changing agriculture scenario. The diversification in agriculture for improving sustainability, profitability and productivity will help in not only increase the farm income but also it provides productive employment. India has the largest producer of fruits (57.73 million tons) after china in the world with its projected value touching 98 MT by the year 2020-2021 (Bhat et al. 2017). India's diverse climate ensures accessibility of all varieties of fruits and vegetables. According to National Horticulture Database published by National Horticulture Board, India has been produced around 86.602 million metric tons of fruits and 169.48 million metric tons of vegetables in the year
2014-15 (GoI, 2014). The total area under fruit cultivation stood at 6.11 million hectares while vegetables it was around 9.54 million hectares. Due to second largest producer of fruits and vegetables it has tremendous opportunities for export. The export of fruits and vegetables from India was ₹ 8,391.41 crores in the year 2015-16 which was comprised of fruits worth ₹ 3,524.50 crores and vegetables worth ₹ 4,866.91 crores (APEDA, 2015). Among the fruit crops, kinnow cultivation in Rajasthan is gaining impetus among the fruit growers due to its profitability and good market value. Kinnow originated as a hybrid of king and willow leaf mandarins (Citrus nobilis $\times$ C . deliciosa) at Riverside, California (Sharma et al. 2007). Kinnow fruits are medium oblate base flattered, deep orange yellow in colour and very juicy (50\%), which 
having good contents of TSS (15\%) and sugar (11\%) with good flavor (Gangwar et al., 2005), and have lot of market potential, which can help in increasing the farm income.

In Rajasthan during 2015-16, kinnow occupies 8.74 thousand ha under cultivation, where SriGanganagar and Bikaner district is well known for its area and production. Sri-Ganganagar district occupied 7.38 thousand ha and Bikaner occupied 0.01 thousand ha area under kinnow cultivation in the year 2015-16, which was 84.40 per cent and 0.21 per cent respectively of the total area of Rajasthan and its production has been realized 133.18 thousand MT in Sri-Ganganagar and 0.01 thousand MT in Bikaner which was 20.28 per cent and 0.009 per cent of the total production of state (GoR, 2016). Therefore, the present paper is an effort to evaluate the kinnow orchards in systematically and scientific manner.

\section{MATERIALS AND METHODS}

The present study was conducted in eight village taking four villages each of SriGanganagar and Bikaner districts as both the districts having highest area and production as well as highest number of solar units for irrigation in the state of Rajasthan. Total 240 kinnow growers were selected purposively and categorised into three categories viz.; solar irrigation system (160 farmers), diesel irrigation system (40 farmers) and electric irrigation system (40 farmers). For analysis of data, economic efficiency measures Net Present Value (NPV), Internal rate of return (IRR), Break-Even point (BEP), Benefit-Cost Ratio $(\mathrm{B}: \mathrm{CR})$ and Payback period $(\mathrm{PB})$ were used.

\section{Analytical Tools}

\section{Net Present Value (NPV)}

Net present value of an investment is the discounted rate of all cash flow and cash inflow of the orchard during its life time. For cash flow analysis 12 per cent rate of interest has been taken in to account. It was computed as:

$$
N P V=\sum_{i=1}^{n} \frac{Y n}{(1+r)^{n}}-C
$$

Where,

$$
Y_{n}=\text { Net cash inflows in the } \mathrm{n}^{\text {th }} \text { year }
$$

$$
\begin{aligned}
& r=\text { Discount rate } \\
& C=\text { Initial cost of investment } \\
& n=\text { Economic life of the mandarin orchard } .
\end{aligned}
$$

\section{Internal Rate of Return (IRR)}

Internal rate of return is the rate of return at which the net present value of a stream of payments/ income is equal to zero. It was calculated as:

$$
I R R=\frac{\left(\begin{array}{l}
\text { lower discount } \\
\text { rate }
\end{array}\right) \times\left(\begin{array}{l}
\text { difference between } \\
\text { two discount rate }
\end{array}\right) \times}{\left(\frac{\mathrm{NPV} \text { at lower discount rate }}{\text { different between two NPV }}\right)}
$$

\section{Benefit Cost Ratio (BCR)}

The benefit cost ratio (BCR) of an investment is the ratio of the discounted value of all cash inflow to the discounted value of all cash inflows during the life of the project. It was estimated as:

$$
B C R=\frac{\text { Gross present value of income }}{\text { Gross present value of costs }}
$$

\section{Break - Even Point}

Break-Even point is the point at which the two curves, total cost curve and total revenue curve intersect each other which indicates the level of production at which the producer neither loss money nor make a profit. It was calculated by using the following formulae:

$$
B E P=\frac{F C}{(P-V C)}
$$

Where,

$F C=$ Fixed cost in per hectare of kinnow

$P=$ Price per quintal of kinnow in rupees

$V C=$ Variable cost per quintal of kinnow in rupees

\section{Pay-Back Period (PB)}

The pay-back period is defined as the length of time required to recover an initial investment through cash flow generated by the investment. It was estimated as:

Pay back period $=\frac{\text { Cost of investment }}{\text { Annual net cash flow }}$ 


\section{RESULTS AND DISCUSSION}

\section{Economic Viability of Kinnow Orchard}

The costs and return estimates were discounted at an annual rate of interest of 12 per cent for the medium term investment for each year and presented category wise from Tables 1 to 3 .

Table 1: Cash flow analysis of kinnow orchard under solar irrigation system

\begin{tabular}{cccccc}
\hline Year & Cost & Return & $\begin{array}{c}\text { Net } \\
\text { returns }\end{array}$ & $\begin{array}{c}\text { Discount } \\
\text { factor at } \\
\mathbf{1 2 \%}\end{array}$ & $\begin{array}{c}\text { Discounted } \\
\text { net cash } \\
\text { flow }\end{array}$ \\
\hline 1 & 93237 & 0 & -93237 & 0.89 & -83247.6 \\
2 & 80969 & 0 & -80969 & 0.80 & -64547.8 \\
3 & 80175 & 0 & -80175 & 0.71 & -57067.1 \\
4 & 81591 & 145920 & 64329 & 0.64 & 40882.01 \\
5 & 83747 & 153600 & 69853 & 0.57 & 39636.72 \\
6 & 85749 & 180480 & 94731 & 0.51 & 47993.61 \\
7 & 87527 & 253440 & 165913 & 0.45 & 75050.78 \\
8 & 87306 & 307200 & 219894 & 0.40 & 88811.69 \\
9 & 87830 & 345600 & 257770 & 0.36 & 92954.27 \\
10 & 88549 & 384000 & 295451 & 0.32 & 95127.35 \\
11 & 89092 & 445440 & 356348 & 0.29 & 102441.5 \\
12 & 89935 & 456960 & 367025 & 0.26 & 94206.19 \\
13 & 90843 & 476160 & 385317 & 0.23 & 88304.7 \\
14 & 91136 & 480000 & 388864 & 0.20 & 79569.34 \\
15 & 91647 & 499200 & 407553 & 0.18 & 74458.46 \\
16 & 90528 & 503040 & 412512 & 0.16 & 67289.66 \\
17 & 90402 & 506880 & 416478 & 0.15 & 60657.65 \\
\hline Total & & 5137920 & 3647658 & & 842521.4 \\
\hline
\end{tabular}

Table 2: Cash flow analysis of kinnow orchard under diesel irrigation system

\begin{tabular}{cccccc}
\hline Year & Cost & Return & $\begin{array}{c}\text { Net } \\
\text { returns }\end{array}$ & $\begin{array}{c}\text { Discount } \\
\text { factor at } \\
\mathbf{1 2 \%}\end{array}$ & $\begin{array}{c}\text { Discounted } \\
\text { net cash } \\
\text { flow }\end{array}$ \\
\hline 1 & 108769 & 0 & -108769 & 0.89 & -97114.86 \\
2 & 85641 & 0 & -85641 & 0.80 & -68272.44 \\
3 & 85334 & 0 & -85334 & 0.71 & -60739.26 \\
4 & 90234 & 153600 & 63366 & 0.64 & 40270.23 \\
5 & 96037 & 172800 & 76763 & 0.57 & 43557.22 \\
6 & 99660 & 192000 & 92340 & 0.51 & 46782.42 \\
7 & 103363 & 245760 & 142397 & 0.45 & 64412.98 \\
8 & 103809 & 303360 & 199551 & 0.40 & 80595.12 \\
9 & 102864 & 376320 & 273456 & 0.36 & 98610.97 \\
10 & 104124 & 384000 & 279876 & 0.32 & 90112.58 \\
11 & 104182 & 433920 & 329738 & 0.29 & 94791.72 \\
12 & 105373 & 430080 & 324707 & 0.26 & 83344.28
\end{tabular}

\begin{tabular}{|c|c|c|c|c|c|}
\hline 13 & 106204 & 464640 & 358436 & 0.23 & 82144.26 \\
\hline 14 & 106485 & 480000 & 373515 & 0.20 & 76428.63 \\
\hline 15 & 106557 & 483840 & 377283 & 0.18 & 68928.17 \\
\hline 16 & 106646 & 491520 & 384874 & 0.16 & 62781.30 \\
\hline 17 & 106592 & 492288 & 385695 & 0.15 & 56174.31 \\
\hline & Total & 5104128 & 3382252 & & 762808 \\
\hline
\end{tabular}

Table 3: Cash flow analysis of kinnow orchard under electric irrigation system

\begin{tabular}{|c|c|c|c|c|c|}
\hline Year & Cost & Return & $\begin{array}{c}\text { Net } \\
\text { returns }\end{array}$ & $\begin{array}{c}\text { Discount } \\
\text { factor at } \\
12 \%\end{array}$ & $\begin{array}{l}\text { Discounted } \\
\text { net cash } \\
\text { flow }\end{array}$ \\
\hline 1 & 97113 & 0 & -97113 & 0.89 & -86707.83 \\
\hline 2 & 83703 & 0 & -83703 & 0.80 & -66727.52 \\
\hline 3 & 81982 & 0 & -81982 & 0.71 & -58353.40 \\
\hline 4 & 84410 & 145920 & 61510 & 0.64 & 39090.65 \\
\hline 5 & 87393 & 153600 & 66207 & 0.57 & 37567.68 \\
\hline 6 & 89906 & 180480 & 90574 & 0.51 & 45887.67 \\
\hline 7 & 92539 & 249600 & 157061 & 0.45 & 71046.59 \\
\hline 8 & 93241 & 303360 & 210119 & 0.40 & 84863.63 \\
\hline 9 & 94257 & 368640 & 274383 & 0.36 & 98945.11 \\
\hline 10 & 95149 & 384000 & 288851 & 0.32 & 93002.34 \\
\hline 11 & 96165 & 433920 & 337755 & 0.29 & 97096.46 \\
\hline 12 & 96764 & 437760 & 340996 & 0.26 & 87525.21 \\
\hline 13 & 96879 & 468480 & 371601 & 0.23 & 85161.43 \\
\hline 14 & 97530 & 476160 & 378630 & 0.20 & 77475.30 \\
\hline 15 & 97633 & 483840 & 386207 & 0.18 & 70558.60 \\
\hline 16 & 97570 & 491520 & 393950 & 0.16 & 64261.77 \\
\hline \multirow[t]{2}{*}{17} & 95276.78 & 495360 & 400083 & 0.15 & 58269.86 \\
\hline & Total & 5072640 & 3495130 & & 798964 \\
\hline
\end{tabular}

Following this procedure, the estimates relating to discounted benefits and discounted costs were obtained for each category of growers. With the help of discounted benefits and costs, the Net Present Value (NPV), Benefit-Cost ratio (B-C ratio), BreakEven point and the Payback period were computed. The economic feasibility indicators of kinnow orchard under different irrigation system were presented in Table 4 . It revealed from table 4 that the net present value of kinnow orchard was estimated of ₹ 842521 under solar irrigation system, ₹ 798964 electric irrigation system and ₹ 762808 under diesel irrigation system. The net present value was found to be higher in kinnow orchard under solar irrigation system as compared to electric irrigation system and diesel irrigation system. It may be due to better management practice and low cost of irrigation compare to diesel and electric irrigation 
system. Internal rate of return ranging from 35 per cent under diesel irrigation system to 38 per cent under solar irrigation system in kinnow orchard indicated that kinnow growing was a profitable enterprise. The B: $\mathrm{C}$ ratio was estimated as 1:2.36 under solar irrigation system, 1:2.23 under electric irrigation and 1:2.08 under diesel irrigation. The benefit cost ratio was found to be more under solar irrigation system because increase productivity of kinnow orchard under solar irrigation system. The $\mathrm{B}-\mathrm{C}$ ratio analysis was found that the investment in kinnow orchard is economically viable. The breakeven point of kinnow orchard was reached at 5.82 ton, 6.00 ton and 4.79 ton under solar irrigation system, electric irrigation system and diesel irrigation system. Further the payback of kinnow orchard was estimated at 7.1 years under solar irrigation system, 7.2 years under electric irrigation system and 7.3 years under diesel irrigation system. Therefore, the kinnow cultivation was economical in the study area. Similarly, Kumar et al. (2017), Kaur and Singla (2016) and Bhat et al. (2011), in which study reported that the kinnow cultivation was economically feasible.

Table 4: Economic feasibility of kinnow orchard under different irrigation system

\begin{tabular}{cccccc}
\hline Category & $\begin{array}{c}\text { NPV } \\
\text { (₹) }\end{array}$ & $\begin{array}{c}\text { IRR } \\
\text { (\%) }\end{array}$ & $\begin{array}{c}\text { B:C } \\
\text { ratio }\end{array}$ & $\begin{array}{c}\text { Break-Even } \\
\text { point (Ton) }\end{array}$ & $\begin{array}{c}\text { Pay-back } \\
\text { period } \\
\text { (Year) }\end{array}$ \\
\hline Solar & 842521 & 38 & 2.36 & 5.82 & 7.1 \\
Electric & 798964 & 37 & 2.23 & 6.00 & 7.2 \\
Diesel & 762808 & 35 & 2.08 & 4.79 & 7.3 \\
\hline
\end{tabular}

\section{CONCLUSION}

The study has revealed that investment in kinnow orchards has been found to be an economically profitable, financially viable and socially acceptable business under solar irrigation, diesel irrigation and electric irrigation system in Rajasthan. The net present value was work out to be ₹ 842521 under solar irrigation system, ₹ 798964 electric irrigation system and $₹ 762808$ under diesel irrigation system. Internal rate of return was found to be 38,37 and 35 per cent under solar irrigation, electric irrigation and diesel irrigation system. Benefit- Cost Ratio was at 2.36, 2.23 and 2.08 under solar irrigation system, electric irrigation system and diesel irrigation system. Break-Even point was 5.82, 6.00 and 4.79 ton under solar irrigation, electric irrigation system and diesel irrigation. Payback period was at 7.1, 7.2 and 7.3 year under solar irrigation, electric irrigation system and diesel irrigation.

\section{ACKNOWLEDGEMENTS}

The authors are very thankful to the Central Agricultural University for providing an opportunity to conduct this Ph.D research from which this paper has been extracted. The authors are also grateful to Ministry of Tribal Affairs, Govt. of India, New Delhi to providing Rajiv Gandhi National Fellowship for higher education to the scholar to complete the Ph.D research.

\section{REFERENCES}

APEDA. 2015. Agricultural \& Processed Food Products Export Development Authority, Ministry of Commerce \& Industry, Government of India.

Bhat, A., Kachroo, J. and Kachroo, D. 2011. Economic appraisal of kinnow Production and its marketing under North-Western Himalayan Region of Jammu. Agricultural Economics Research Review, 24(2): 283-290.

Gangwar, L.S., Ilyas, S.M., Singh, D. and Kumar, S. 2005. An economic evaluation of kinnow mandarin cultivation in Punjab. Agricultural Economics Research Review, 18(1): 71-80.

GoI. 2014. Indian horticulture data base. Government of India, NHB.

GoR. 2016. Directorate of Horticulture, Government of Rajasthan.

Kaur, M. and Singla, N. 2016. An economic analysis of kinnow cultivation and marketing in Fazilka District of Punjab. Indian Journal of Economics and Development, 12(4): 711-718.

Kumar, N., Duhan, A., Bhatia, J. and Malik, V. 2017. Economic appraisal of kinnow production and its marketing in Sirsa district of Haryana, India. International Journal of Current Microbiology and Applied Sciences, 6(11): 4045-4053.

Sharma, S., Singh, B., Rani, G., Zaidi, A.A., Hallan, V., Nagpal, A. and Virk, G.S. 2007. Production of Indian citrus ringspot virus free plants of kinnow employing chemotherapy coupled with shoot tip grafting. Journal of Central European Agriculture, 8(1): 1-8. 